\title{
Beyond morbidity and mortality in reintroduction programmes: changing health parameters in reintroduced eastern bettongs Bettongia gaimardi
}

\author{
Timothy J. Portas, Ross B. Cunningham, David Spratit, Joanne Devinn \\ Peter Holz, William Batson, Jane Owens and Adrian D. Manning
}

\begin{abstract}
The eastern bettong Bettongia gaimardi, a potoroid marsupial, has been extinct on the Australian mainland since the 1920s. Sixty adult bettongs were reintroduced from the island of Tasmania to two predator-free fenced reserves on mainland Australia. We examined baseline health parameters (body weight, haematology and biochemistry, parasites and infectious disease exposure) in a subset of 30 (13 male, $17 \mathrm{female}$ ) individuals at translocation and again at 12-24 months post-reintroduction. The mean body weight increased significantly post-reintroduction but there were no significant differences in body weight between the two reintroduction sites or between the sexes in response to reintroduction. Differences were evident in multiple haematological and biochemical variables post-reintroduction but there were few differences between the two reintroduced populations or between the sexes in response to reintroduction. Ectoparasite assemblages differed, with five of 13 species failing to persist, and an additional four species were identified post-reintroduction. None of the bettongs had detectable antibodies to the alphaherpesviruses Macropodid herpesvirus 1 and 2 post-reintroduction, including one individual that was seropositive at translocation. Similarly, the novel gammaherpesvirus potoroid herpesvirus 1 was not detected by polymerase chain reaction (PCR) in any of the bettongs post-reintroduction, including one individual that was PCR-positive at translocation. None of the bettongs had detectable antibodies to Toxoplasma gondii either at translocation or post-reintroduction. Our data demonstrate changing baseline health parameters in eastern bettongs following reintroduction to the Australian mainland are suggestive of improved health in the reintroduced populations, and provide additional
\end{abstract}

Timothy J. Portas (Corresponding author) and Peter Holz Veterinary and Research Centre, Tidbinbilla Nature Reserve, RMB 141, Via Tharwa, Australian Capital Territory 2620, Australia. E-mail tandsportas@bigpond.com

Ross B. Cunningham, William Batson and Adrian D. Manning Fenner School of Environment and Society, Australian National University College of Medicine, Biology and Environment, Canberra, Australia

DAVID SpRATT Australian National Wildlife Collection, CSIRO National Research Collections Australia, Canberra, Australia

Joanne DevLin and JANe Owens Faculty of Veterinary Science, the University of Melbourne, Parkville, Victoria, Australia

Received 29 July 2015. Revision requested 28 October 2015.

Accepted 3 November 2015. First published online 28 March 2016. metrics for assessing the response of macropodoids to reintroduction.

Keywords Bettongia gaimardi, biochemistry, disease, eastern bettong, haematology, health evaluation, parasite, reintroduction

\section{Introduction}

The underlying health status of individual animals can I influence survival during translocation and establishment in reintroduction programmes, and disease may influence the persistence of populations in the longer term (Kock et al., 2007; Cabezas et al., 2011; Clarke et al., 2013). Disease may also have an impact on sympatric species at reintroduction sites, and detailed recommendations for assessing and managing disease risk in wildlife translocations have been published (Leighton, 2002; Travis et al., 2006; Jakob-Hoff et al., 2014). Despite this, comprehensive health evaluations are not routinely undertaken, and the potential for disease to influence outcomes is often not considered nor adequately managed in reintroduction programmes (Mathews et al., 2006; Deem et al., 2012). Various health parameters in freeranging wildlife species, including haematology and biochemistry, and parasite assemblages, are influenced by a range of environmental and host factors and could be expected to change when species are reintroduced to environments from which they have been extirpated (Schultz et al., 2011; Robert \& Schwanz, 2013; Webster et al., 2014). Evaluation of changes to health parameters pre- and postreintroduction could potentially be used to assess the longer term physiological response of species to reintroduction and may be a useful adjunct to traditional metrics (survival, dispersal and reproductive success) used to assess reintroduction outcomes (Ewen et al., 2012; Nichols \& Armstrong, 2012; Maceda-Veiga et al., 2015).

The eastern bettong Bettongia gaimardi is a small, nocturnal, predominantly mycophagous, potoroid marsupial that has been extinct on the Australian mainland since the 1920 (Claridge et al., 2007). In 2011-2012 60 adults were reintroduced from the island of Tasmania to two predatorfree fenced reserves, Tidbinbilla Nature Reserve and Mulligans Flat Woodland Sanctuary, in the Australian Capital Territory (Batson et al., in press). Comprehensive 
health assessments were undertaken during translocation, and baseline health and disease parameters were established for the species (Portas et al., 2014). We hypothesized that health parameters of eastern bettongs would change postreintroduction and could therefore be useful measures for assessing the effect of reintroduction on bettong health beyond direct observations of morbidity and mortality. Here we compare body weight, haematology and biochemistry, parasite assemblages, and disease exposure (Toxoplasma gondii, macropodoid herpesviruses) of a subset (13 males, 17 females) of the population pre- and post-reintroduction. We also compare the haematology and biochemistry of the populations at the two reintroduction sites and between the sexes in response to reintroduction.

\section{Study area}

Collection sites for free-ranging bettongs in Tasmania have been described previously and included eight locations representing a mix of remnant native forest, forestry plantations and agricultural land (Portas et al., 2014; Batson et al., in press). Mulligans Flat Woodland Sanctuary, in the Australian Capital Territory, is a 400 ha remnant of highly threatened box-gum grassy woodland that is the subject of intensive experimental restoration efforts (Manning et al., 2011; Shorthouse et al., 2012). Tidbinbilla Nature Reserve, also in the Australian Capital Territory, incorporates a fenced sanctuary in an area of wet sclerophyll forest and open grassland for the conservation management of threatened Australian species (Fig. 1).

\section{Methods}

Previously we established baseline health and disease parameters in 60 adult ( $>1$ year, on the basis of dentition) eastern bettongs (19 male, 41 female) live-trapped during July-October 2011 and April-September 2012 in Tasmania and reintroduced to Tidbinbilla Nature Reserve and Mulligans Flat Woodland Sanctuary (Portas et al., 2014). Bettongs released into Mulligans Flat (8 males, 10 females) were monitored via global positioning system/VHF collars and live-trapping approximately every 3 months. They received no supplemental food and the population was unmanaged. Bettongs at Tidbinbilla ( 5 males, 7 females) were housed in small groups in natural bushland enclosures (2.6$9.4 \mathrm{ha}$ ) and managed to maximize genetic diversity of offspring; they received supplemental food, including fresh locally available produce and a commercially available pellet, at least weekly. Monitoring was limited to remote observation of feed stations via camera, and live-trapping approximately every 3 months.

Trapping, sedation and anaesthetic procedures at translocation have been described previously (Portas et al., 2014).

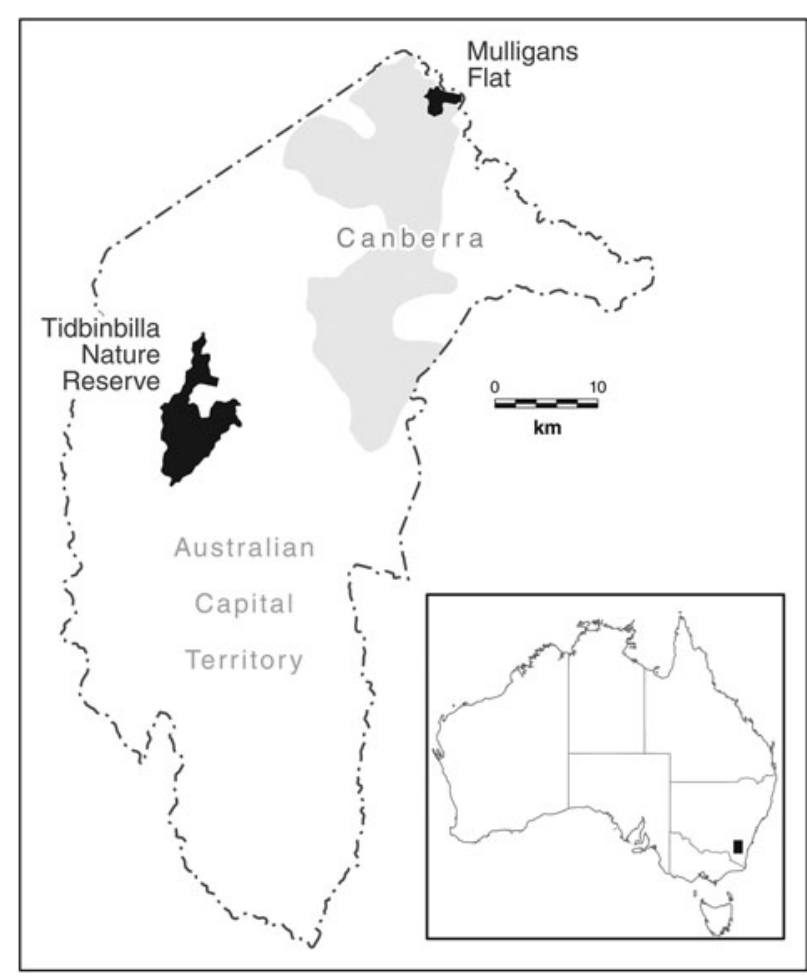

FIG. 1 Location of the two reintroduction sites, Mulligans Flat Woodland Sanctuary and Tidbinbilla Nature Reserve within the Australian Capital Territory.

At 12-24 months post-reintroduction (May-November 2013) bettongs were captured at both reintroduction sites at night, using padded cage traps baited with a mixture of oats and peanut butter. Traps were set at dusk and checked 1-4 hours later. Bettongs were removed from traps and placed in cloth bags before being processed on site. Anaesthesia was induced and maintained using isoflurane in oxygen delivered via a mask. Post anaesthesia, bettongs recovered in cloth bags for up to 1 hour before being released at the capture site.

The physical examination process, sample and data collection, and sample processing are described in detail in Portas et al. (2014). Briefly, the following were performed: physical examination; body weight was recorded; pes length was measured; ticks and fleas were collected using forceps and fixed in $70 \%$ ethanol; mites and lice were collected from skin and hair scrapings in glycerine; blood was collected from the lateral coccygeal vein for assessment of haematological and biochemical parameters and serology (Toxoplasma gondii, Macropodid herpesviruses 1 and 2 [MaHV-1, MaHV-2]); pooled swabs from the conjunctival, nasal and urogenital mucosa were collected for the detection of herpesvirus DNA using polymerase chain reaction (PCR); and faecal samples were collected and assessed using the sodium nitrate floatation technique for endoparasite ova. Bettongs were weighed to the nearest gram using electronic scales. For females with pouch young present, 
weights were adjusted by subtracting the estimated weight of the pouch young (Batson et al., 2015). We calculated body condition index using the residuals of a linear regression of body weight against pes length (Johnson, 1994). Individuals were identified by the subcutaneous placement of a microchip.

Haematological and biochemical analyses were performed by Vetnostics (North Ryde, Australia) within 24 hours of collection. The following were measured: haematocrit, haemoglobin, red blood cell count, mean corpuscular volume, mean corpuscular haemoglobin, mean corpuscular haemoglobin concentration, platelet count, neutrophils, lymphocytes, monocytes, eosinophils, basophils, sodium, potassium, chloride, bicarbonate, anion gap, urea, creatinine, glucose, bilirubin, aspartate amino transferase, alanine transaminase, gamma glutamyl transferase, alkaline phosphatase, total protein, globulin, albumin, albumin/globulin ratio, calcium, phosphate, creatine kinase, cholesterol and triglyceride. Any haematological and biochemical variables that were significantly different post reintroduction, and potentially influenced by nutrition, were reassessed after statistically adjusting for body weight.

Toxoplasma gondii serology was performed at the Department of Primary Industries, Water and Environment, Mount Pleasant Laboratories, Launceston, Australia, using the direct and modified agglutination tests for antibodies to T. gondii (Johnson et al., 1989). Both tests were performed on all sera at translocation, after which time the laboratory ceased to offer the direct test, and sera collected postreintroduction were assayed using the modified test only. Herpesvirus serology and detection of herpesvirus DNA by PCR were performed at the Faculty of Veterinary Science, University of Melbourne, Parkville, Australia, using previously described techniques (Vaz et al., 2013).

Haematological and biochemical values (response variables) varied at two levels: between individuals and within individuals. Candidate explanatory variables such as weight varied at both the individual and within-individual levels, whereas the factors sex and site (Tidbinbilla vs Mulligans Flat) varied only at the individual level. The design variable reintroduction (pre- vs post-) varied only at the withinindividual level. Given the multilevel sampling design and data structure, these data were analysed within the framework of general linear mixed models using restricted maximum likelihood, with significance assumed at $\mathrm{P}<0.05$. For overall inference, information was combined across the two levels. Statistical computation was performed using GenStat 17 (VSN International Ltd., Hemel Hempstead, UK).

\section{Results}

We calculated the body condition index of the reintroduced eastern bettongs but found no significant relationship between body weight and pes length (Fig. 2). Body weight increased $(F$ pr. $<0.001)$ from a mean of $1.69 \pm$ SE $0.024 \mathrm{~kg}$ at

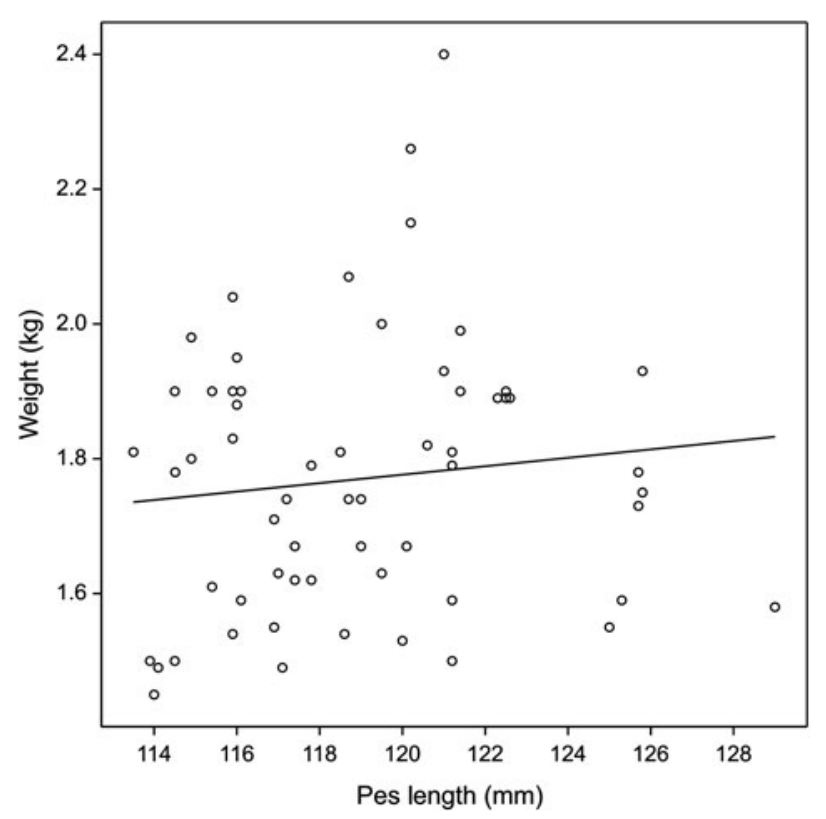

FIG. 2 Fitted and observed relationship from regression analysis of body weight vs pes length in eastern bettongs Bettongia gaimardi reintroduced from Tasmania to the Australian Capital Territory, Australia (Fig. 1).

translocation to $1.83 \pm \mathrm{SE} 0.024 \mathrm{~kg}$ post-reintroduction. There were no significant differences between mean body weights at the two reintroduction sites or between males and females in response to reintroduction.

Haematocrit, haemoglobin, red blood cell count, mean corpuscular haemoglobin and platelets increased whereas white blood cell count, neutrophils, lymphocytes and monocytes decreased post-reintroduction (Table 1). There were fewer differences between haematological parameters at the two reintroduction sites, with higher platelets, white blood cell count, neutrophils and monocytes in the Tidbinbilla population than the Mulligans Flat population (Table 1). There were limited differences in response to reintroduction between the sexes other than for platelets, which increased more $(\mathrm{P}=0.034)$, and white blood cell count, which decreased more $(\mathrm{P}=0.046)$ in males. Potassium, anion gap, urea, creatinine, glucose, globulin and triglyceride were all higher post-reintroduction. Sodium, chloride, bicarbonate, aspartate amino transferase, alanine transaminase, gamma glutamyl transferase, albumin/globulin ratio, phosphate, creatine kinase and cholesterol were all lower post-reintroduction (Table 2). There were few differences between biochemical parameters at the two reintroduction sites, with lower sodium and bicarbonate, and higher anion gap, creatinine, glucose and alkaline phosphatase in the Tidbinbilla population (Table 2). The only difference between the sexes in response to reintroduction was their phosphate level $(\mathrm{P}=0.046)$, which decreased more in females. Haematocrit $(\mathrm{P}<0.001)$, haemoglobin $(\mathrm{P}=0.005)$, red cell count $(\mathrm{P}=0.001)$, 
TABLE 1 Comparison of haematological variables (mean \pm SE) in 30 (13 male, 17 female) eastern bettongs Bettongia gaimardi reintroduced from Tasmania to Mulligans Flat Woodland Sanctuary (MFWS) and Tidbinbilla Nature Reserve (TNR) in the Australian Capital Territory (ACT), Australia, at translocation, post-reintroduction and between populations at the two reintroduction sites.

\begin{tabular}{|c|c|c|c|c|c|c|}
\hline \multirow[b]{2}{*}{ Variable $^{1}$} & \multirow{2}{*}{$\frac{\text { At translocation }}{\text { Tasmania }}$} & \multicolumn{2}{|c|}{ Post-reintroduction } & \multicolumn{3}{|c|}{ Reintroduction site } \\
\hline & & ACT & $\mathrm{P}$ & MFWS & TNR & $\mathrm{P}$ \\
\hline Haematocrit (\%) & $0.399 \pm 0.006$ & $0.456 \pm 0.006$ & $<0.001^{\star}$ & $0.445 \pm 0.009$ & $0.475 \pm 0.011$ & 0.106 \\
\hline $\mathrm{Hb}\left(\mathrm{gL}^{-1}\right)$ & $133.4 \pm 2.24$ & $154.9 \pm 2.24$ & $<0.001^{\star}$ & $152.5 \pm 2.8$ & $159.0 \pm 3.6$ & 0.337 \\
\hline $\mathrm{RBC}\left(\times 10^{12} \mathrm{~L}^{-1}\right)$ & $9.52 \pm 0.156$ & $10.80 \pm 0.156$ & $<0.001^{\star}$ & $10.56 \pm 0.24$ & $11.22 \pm 0.3$ & 0.161 \\
\hline MCV (fL) & $41.50 \pm 0.53$ & $42.50 \pm 0.53$ & 0.195 & $41.86 \pm 0.96$ & $43.61 \pm 1.17$ & 0.275 \\
\hline $\mathrm{MCH}(\mathrm{pg})$ & $14.13 \pm 0.10$ & $14.46 \pm 0.10$ & $0.029^{*}$ & $14.65 \pm 0.21$ & $14.14 \pm 0.25$ & 0.104 \\
\hline $\mathrm{MCHC}\left(\mathrm{gL}^{-1}\right)$ & $335.7 \pm 1.99$ & $339.6 \pm 1.99$ & 0.177 & $342.1 \pm 3.6$ & $335.4 \pm 4.4$ & 0.206 \\
\hline Platelets $\left(\times 10^{9} \mathrm{~L}^{-1}\right)$ & $387.9 \pm 13.13$ & $436.9 \pm 13.13$ & $0.016^{*}$ & $405.9 \pm 28.9$ & $490.4 \pm 3.7$ & $0.014^{*}$ \\
\hline $\mathrm{WBC}\left(\times 10^{9} \mathrm{~L}^{-1}\right)$ & $3.58 \pm 0.15$ & $2.64 \pm 0.15$ & $<0.001^{\star}$ & $2.09 \pm 0.24$ & $3.59 \pm 0.03$ & $0.002^{*}$ \\
\hline Neutrophils $\left(\times 10^{9} \mathrm{~L}^{-1}\right)$ & $2.20 \pm 0.13$ & $1.34 \pm 0.13$ & $<0.001^{\star}$ & $0.96 \pm 0.19$ & $2.00 \pm 0.24$ & $0.010^{*}$ \\
\hline Lymphocytes $\left(\times 10^{9} \mathrm{~L}^{-1}\right)$ & $1.38 \pm 0.09$ & $1.15 \pm 0.09$ & $0.026^{\star}$ & $1.00 \pm 0.14$ & $1.34 \pm 0.17$ & 0.216 \\
\hline Monocytes $\left(\times 10^{9} \mathrm{~L}^{-1}\right)$ & $0.15 \pm 0.08$ & $0.09 \pm 0.08$ & $0.004^{*}$ & $0.06 \pm 0.017$ & $0.14 \pm 0.021$ & $0.040^{*}$ \\
\hline Eosinophils $\left(\times 10^{9} \mathrm{~L}^{-1}\right)$ & $0.03 \pm 0.01$ & $0.05 \pm 0.01$ & 0.446 & $0.035 \pm 0.014$ & $0.075 \pm 0.018$ & 0.278 \\
\hline
\end{tabular}

${ }^{1} \mathrm{Hb}$, haemoglobin; RBC, red blood cell count; MCV, mean corpuscular volume; MCH, mean corpuscular haemoglobin; MCHC, mean corpuscular haemoglobin concentration; WBC, white blood cell count

${ }^{\star}$ Denotes statistically significant difference between values

TABLE 2 Comparison of biochemical variables (mean \pm SE) in 30 ( 13 male, 17 female) eastern bettongs reintroduced from Tasmania to Mulligans Flat Woodland Sanctuary (MFWS) and Tidbinbilla Nature Reserve (TNR) in the Australian Capital Territory (ACT), Australia, at translocation, post-reintroduction and between populations at the two reintroduction sites.

\begin{tabular}{|c|c|c|c|c|c|c|}
\hline \multirow[b]{2}{*}{ Variable $^{1}$} & \multirow{2}{*}{$\frac{\text { At translocation }}{\text { Tasmania }}$} & \multicolumn{2}{|c|}{ Post-reintroduction } & \multicolumn{3}{|c|}{ Reintroduction site } \\
\hline & & ACT & $\mathrm{P}$ & MFWS & TNR & $\mathrm{P}$ \\
\hline Sodium $\left(\mathrm{mmol} \mathrm{L}^{-1}\right)$ & $147.20 \pm 0.56$ & $143.30 \pm 0.56$ & $<0.001^{*}$ & $144.92 \pm 0.8$ & $140.50 \pm 1.0$ & $0.012^{\star}$ \\
\hline Potassium $\left(\mathrm{mmol} \mathrm{L}^{-1}\right)$ & $3.67 \pm 0.32$ & $4.74 \pm 0.32$ & $0.028^{\star}$ & $4.78 \pm 0.47$ & $4.67 \pm 0.56$ & 0.914 \\
\hline Chloride $\left(\mathrm{mmol} \mathrm{L}^{-1}\right)$ & $106.87 \pm 0.63$ & $101.30 \pm 0.63$ & $<0.001^{\star}$ & $102.77 \pm 0.9$ & $98.77 \pm 1.1$ & 0.041 \\
\hline Bicarbonate $\left(\mathrm{mmol} \mathrm{L}^{-1}\right)$ & $29.10 \pm 0.62$ & $23.60 \pm 0.62$ & $<0.001^{\star}$ & $25.48 \pm 0.77$ & $20.36 \pm 0.99$ & $0.009^{*}$ \\
\hline Anion gap $\left(\mathrm{mmol} \mathrm{L}^{-1}\right)$ & $15.03 \pm 0.80$ & $22.38 \pm 0.80$ & $<0.001^{\star}$ & $20.26 \pm 1.04$ & $26.05 \pm 1.26$ & $0.021^{*}$ \\
\hline Urea $\left(\mathrm{mmol} \mathrm{L}^{-1}\right)$ & $6.05 \pm 0.40$ & $8.26 \pm 0.40$ & $<0.001^{\star}$ & $7.52 \pm 0.54$ & $9.52 \pm 0.68$ & 0.105 \\
\hline Creatinine $\left(\mu \mathrm{mol} \mathrm{L}{ }^{-1}\right)$ & $41.7 \pm 1.78$ & $57.1 \pm 1.78$ & $<0.001^{\star}$ & $50.4 \pm 2.72$ & $68.7 \pm 3.43$ & $0.002^{*}$ \\
\hline Glucose $\left(\mathrm{U} \mathrm{L}^{-1}\right)$ & $11.33 \pm 0.67$ & $17.80 \pm 0.67$ & $<0.001^{\star}$ & $14.62 \pm 1.2$ & $23.29 \pm 1.42$ & $<0.001^{*}$ \\
\hline Bilirubin $\left(\mathrm{U} \mathrm{L}^{-1}\right)$ & $1.03 \pm 0.08$ & $1.13 \pm 0.08$ & 0.409 & $1.20 \pm 0.11$ & $1.019 \pm 0.14$ & 0.473 \\
\hline $\operatorname{AST}\left(\mathrm{U} \mathrm{L}^{-1}\right)$ & $176.2 \pm 5.91$ & $46.2 \pm 5.91$ & $<0.001^{\star}$ & $50.1 \pm 9.27$ & $40.1 \pm 11.63$ & 0.572 \\
\hline $\operatorname{ALT}\left(\mathrm{U} \mathrm{L}^{-1}\right)$ & $84.7 \pm 3.82$ & $32.6 \pm 3.82$ & $<0.001^{\star}$ & $34.3 \pm 5.41$ & $29.7 \pm 6.87$ & 0.689 \\
\hline GGT $\left(\mathrm{U} \mathrm{L}^{-1}\right)$ & $16.47 \pm 0.91$ & $14.61 \pm 0.91$ & $0.021^{\star}$ & $13.26 \pm 1.15$ & $13.37 \pm 1.46$ & 0.968 \\
\hline $\operatorname{ALP}\left(\mathrm{U} \mathrm{L}^{-1}\right)$ & $1,679 \pm 164.1$ & $1,421 \pm 164.1$ & 0.275 & $1,821 \pm 392.2$ & $728 \pm 443.6$ & $0.033^{*}$ \\
\hline Protein $\left(\mathrm{gL}^{-1}\right)$ & $55.13 \pm 0.75$ & $56.80 \pm 0.75$ & 0.129 & $56.88 \pm 1.21$ & $56.66 \pm 1.51$ & 0.923 \\
\hline Albumin $\left(\mathrm{gL}^{-1}\right)$ & $40.56 \pm 0.76$ & $39.78 \pm 0.76$ & 0.138 & $40.13 \pm 1.22$ & $37.13 \pm 1.52$ & 0.189 \\
\hline Globulin $\left(\mathrm{gL}^{-1}\right)$ & $14.47 \pm 0.66$ & $17.77 \pm 0.66$ & $0.002^{*}$ & $16.57 \pm 1.04$ & $19.53 \pm 1.31$ & 0.166 \\
\hline Albumin/globulin ratio & $4.03 \pm 0.41$ & $2.37 \pm 0.41$ & $0.013^{*}$ & $2.37 \pm 0.56$ & $2.07 \pm 0.72$ & 0.807 \\
\hline Calcium $\left(\mathrm{mmol} \mathrm{L}^{-1}\right)$ & $2.29 \pm 0.02$ & $2.30 \pm 0.02$ & 0.793 & $2.27 \pm 0.03$ & $2.36 \pm 0.04$ & 0.147 \\
\hline Phosphate $\left(\mathrm{mmol} \mathrm{L}^{-1}\right)$ & $2.51 \pm 0.13$ & $2.01 \pm 0.13$ & $0.009^{*}$ & $2.214 \pm 0.18$ & $1.66 \pm 0.21$ & 0.148 \\
\hline Creatine kinase $\left(\mathrm{U} \mathrm{L}^{-1}\right)$ & $24,018 \pm 1,463.9$ & $1,005 \pm 1,463.9$ & $<0.001^{\star}$ & $118 \pm 2,015$ & $2,537 \pm 2,565$ & 0.580 \\
\hline Cholesterol $\left(\mathrm{mmol} \mathrm{L}^{-1}\right)$ & $3.894 \pm 0.13$ & $3.050 \pm 0.13$ & $0.002^{*}$ & $2.94 \pm 0.20$ & $2.96 \pm 0.25$ & 0.952 \\
\hline Triglyceride $\left(\mathrm{mmol} \mathrm{L}^{-1}\right)$ & $0.867 \pm 0.10$ & $1.51 \pm 0.10$ & $<0.001^{\star}$ & $1.46 \pm 0.13$ & $1.58 \pm 0.16$ & 0.704 \\
\hline
\end{tabular}

${ }^{1}$ AST, aspartate amino transferase; ALT, alanine transaminase; GGT, gamma glutamyl transferase; ALP, alkaline phosphatase

${ }^{\star}$ Denotes statistically significant difference between values

creatinine $(\mathrm{P}<0.001)$ and triglycerides $(\mathrm{P}=0.004)$ were positively related to body weight, whereas mean corpuscular haemoglobin $(\mathrm{P}=0.280)$, urea $(\mathrm{P}=0.622)$ and globulin $(\mathrm{P}=0.155)$ were not.
Sera from all 30 bettongs were negative for antibodies to T. gondii at both time points. One female had detectable antibodies to alphaherpesviruses MaHV-1 and MaHV-2, as determined by serum neutralization assay at translocation, 
TABLE 3 Ectoparasite assemblages found on eastern bettongs reintroduced from Tasmania to the Australian Capital Territory, Australia, at translocation and post-reintroduction, and accession numbers.

\begin{tabular}{|c|c|c|c|}
\hline Species & $\begin{array}{l}\text { Present at } \\
\text { translocation }\end{array}$ & $\begin{array}{l}\text { Present } \\
\text { post-reintroduction }\end{array}$ & Accession number(s) \\
\hline \multicolumn{4}{|l|}{ Listrophoridae } \\
\hline Paraheterodoxus erinaceus & No & Yes & AR 1594 \\
\hline Paraheterodoxus? n. sp. & Yes & Yes & AR 1572, 1574 \\
\hline Hetrodoxus cf. ualabati & No & Yes & AR 1590 \\
\hline \multicolumn{4}{|l|}{ Trombiculidae } \\
\hline Eutrombicula macropus & No & Yes & AR 1593 \\
\hline Guntheria cf. pertinax & Yes & Yes & AR 1579 \\
\hline Guntheria cf. shareli & No & Yes & AR 1614 \\
\hline \multicolumn{4}{|l|}{ Laelapidae } \\
\hline Haemolaelaps hatteni & Yes & No & AR 1575 \\
\hline Thadeua greeni & Yes & Yes & AR 1585 \\
\hline \multicolumn{4}{|l|}{ Atopomelidae } \\
\hline Cytostethum (Metacytostethum) intermedium & Yes & Yes & AR 1576 \\
\hline Cytostethum (Metacytostethum) tasmaniense & Yes & Yes & AR 1576 \\
\hline Cytostethum (Metacytostethum) thetis & Yes & Yes & AR 1576 \\
\hline Cytostethum (Metacytostethum) wallabia & Yes & Yes & AR 1576 \\
\hline \multicolumn{4}{|l|}{ Ixodidae } \\
\hline Ixodes cornuatus & Yes & No & AR 1586 \\
\hline Ixodes tasmani & Yes & No & AR 1587 \\
\hline Ixodes trichosuri & Yes & Yes & AR 1571 \\
\hline \multicolumn{4}{|l|}{ Pygiopsyllidae } \\
\hline Pygiopsylla zethi & Yes & No & AR 1573 \\
\hline \multicolumn{4}{|l|}{ Stephanocercidae } \\
\hline Stephanocircus harrisoni & Yes & No & AR 1588 \\
\hline
\end{tabular}

but had no detectable antibodies 19 months later. The other 29 individuals were seronegative at translocation and postreintroduction. A pooled nasal/conjunctival/urogenital tract swab from a single male was positive for herpesvirus DNA (potoroid herpesvirus 1, PotHV-1), using PCR at translocation, but was negative 12 months later. The other 29 were negative for herpesvirus DNA, using PCR at both time points.

Fleas, lice, mites and ticks recovered from bettongs were deposited in the Australian National Wildlife Collection, CSIRO, Canberra. Five ectoparasite species (Haemolaelaps hatteni, Ixodes cornuatus, I. tasmani, Pygiopsylla zethi, Stephanocircus harrisoni) present at translocation were not recovered post-reintroduction; however, an additional four species (Paraheterodoxus erinaceus, Hetrodoxus cf. ualabti, Eutrombicula macropus, Guntheria cf. shareli) were recovered post-reintroduction (Table 3). Details of the prevalence of endo- and ectoparasites recovered from bettongs at both time points are in Table 4.

\section{Discussion}

Our data demonstrate changing health parameters in eastern bettongs following reintroduction to the Australian mainland and are suggestive of improved health in the
TABLE 4 Prevalence of parasites on a sample of 30 eastern bettongs reintroduced from Tasmania to the Australian Capital Territory, Australia, at translocation and post-reintroduction.

\begin{tabular}{|c|c|c|}
\hline \multirow[b]{2}{*}{ Parasite } & \multirow{2}{*}{$\begin{array}{l}\text { At translocation } \\
\text { No. of individuals } \\
\text { affected (\%) }\end{array}$} & \multirow{2}{*}{$\begin{array}{l}\text { Post-reintroduction } \\
\text { No. of individuals } \\
\text { affected (\%) }\end{array}$} \\
\hline & & \\
\hline \multicolumn{3}{|l|}{ Endoparasites } \\
\hline Strongylid eggs & $13(43.3)$ & $22(73.3)$ \\
\hline Strongylid larvae & $2(6.7)$ & $6(20)$ \\
\hline Capillariid-like eggs & $1(3.3)$ & $0(0)$ \\
\hline Eimeria gaimardi & $3(10)$ & $5(16.7)$ \\
\hline \multicolumn{3}{|l|}{ Ectoparasites } \\
\hline Ticks & $23(76.7)$ & $2(6.7)$ \\
\hline Lice & $7(23.3)$ & $11(36.7)$ \\
\hline Fleas & $13(43.3)$ & $0(0)$ \\
\hline Mites & $28(93.3)$ & $13(43.3)$ \\
\hline
\end{tabular}

reintroduced populations. Despite recommendations for ongoing health monitoring in reintroduction programmes there are few reports of continued monitoring beyond translocation and establishment (Kock et al., 2007; Work et al., 2010). Furthermore, post-reintroduction health monitoring is often limited to direct observations of morbidity and mortality, with changes at a physiological level receiving scant attention. Our data demonstrate the value of ongoing 
comprehensive health evaluations for assessing the response of individuals and populations to reintroduction, and can be used as an adjunct to traditional measures for assessing reintroduction outcomes.

Body condition index, usually calculated as the residuals of a linear regression of body weight against a linear morphometric measure, has been used to assess body condition in a number of macropodoid species (Stirrat, 2003; Robert \& Schwanz, 2013). Despite previous validation of the use of body weight and pes length for calculating body condition index in eastern bettongs, through calculating total body water and hence proportion of body fat via isotope dilution, we found no relationship in this study (Johnson, 1994). The reasons for this were not readily evident but the assumptions that underlie the calculation of body condition index using this method have been questioned previously (Green, 2001). Consequently we assessed changes in body weight in response to reintroduction. Despite the fact that bettongs at Tidbinbilla Nature Reserve received supplemental food there was no difference in mean body weight between the two reintroduced populations, and body weight increased at both sites. This, coupled with haematological and biochemical data, suggests the source populations in Tasmania were experiencing suboptimal nutrition.

Body condition has been positively correlated with the availability of hypogeous fungi in both eastern and northern bettongs Bettongia tropica (Johnson, 1994; Johnson \& McIlwee, 1997). We made no attempt to quantify dietary hypogeous fungi intake or assess the nutritional quality of the diet at the source habitat or reintroduction sites. However, bettongs were collected from agricultural land and disturbed and fragmented habitat in Tasmania; sites which may have represented suboptimal habitat and afforded poorer quality diets. Alternatively, lower population densities and lack of competition at the reintroduction sites may have resulted in greater resource availability, improved nutrition and hence higher body weights for reintroduced bettongs.

Comparisons of haematological and biochemical variables at translocation and post-reintroduction revealed significant differences in a range of variables. Some speciesspecific variability in the response of haematological and biochemical parameters to changing environmental conditions has been found in other macropodoids (Ealey \& Main, 1967; Shield, 1971; Algar et al., 1988; Stirrat, 2003; Pacioni et al., 2013; Robert \& Schwanz, 2013). Of particular interest in eastern bettongs were increases in haematocrit, haemoglobin, red cell count, creatinine and triglycerides postreintroduction. These variables were positively correlated with weight (rather than reintroduction per se), suggesting they may be useful measures of nutritional status in eastern bettongs.

Haemoglobin concentration in eastern bettongs postreintroduction was comparable to reference values reported for the closely related woylie Bettongia penicillata in
Western Australia, suggesting post-reintroduction haemoglobin concentration may be more representative of normal values for the eastern bettong in optimal environments (Pacioni et al., 2013). Lower haemoglobin concentrations in response to seasonal declines in diet quality have been demonstrated in western grey kangaroos Macropus fuliginosus, common wallaroos $M$. robustus and quokkas Setonix brachyurus (Ealey \& Main, 1967; Shield, 1971; Algar et al., 1988). In woylies, haemoglobin concentration was also shown to have a positive association with rainfall, presumably mediated via changing nutritional content of forage species (Pacioni et al., 2013). In contrast, seasonal changes in nutrition did not influence haemoglobin concentration in agile wallabies Macropus agilis or allied rock wallabies Petrogale assimilis and there was no significant difference in haemoglobin concentration between three subpopulations of tammar wallabies Macropus eugenii living in separate habitats of variable nutritional quality (Spencer \& Speare, 1992; Stirrat, 2003; Robert \& Schwanz, 2013).

Increases in red cell count and haematocrit in eastern bettongs post-reintroduction may also be explained by improved nutrition at the reintroduction sites. In woylies, red cell count and haematocrit have also been shown to have a positive association with rainfall (Pacioni et al., 2013). In agile wallabies from the wet-dry tropics, haematocrit (but not red cell count) was lower during the dry season, and poor nutrition was postulated as the cause (Stirrat, 2003). Haematocrit can increase in response to haemoconcentration but eastern bettongs at the source locations and the reintroduction sites had free access to water, making haemoconcentration secondary to dehydration unlikely. Additionally, total protein, albumin and haematocrit all increase in dehydrated individuals, and in this study neither total protein nor albumin values increased significantly post-reintroduction.

We interpreted the neutrophilia, lymphocytosis and monocytosis observed in bettongs at translocation as a physiological leucocytosis in response to the prolonged period of confinement and transportation prior to sampling (Stockham \& Scott, 2008). The higher white blood cell, neutrophil and monocyte count observed in the Tidbinbilla population compared with the Mulligans Flat population may reflect variable levels of physiological stress at the two sites. Eastern bettongs at Tidbinbilla have higher faecal corticosteroid metabolites (W. Batson, unpubl. data), which could support the possibility of an unknown environmental stressor.

Creatinine is influenced by muscle mass and renal function (Stockham \& Scott, 2008). We attributed the increased creatinine in bettongs post-reintroduction to the greater body mass of the animals rather than dehydration. Reduced creatinine concentrations have been observed in malnourished white-tailed deer Odocoileus virginianus and in tammar wallabies under nutritional stress 
(Delgiudice et al., 1990; Robert \& Schwanz, 2013). In contrast, creatinine concentrations were not significantly different, despite significant changes in body mass, in agile wallabies experiencing seasonal nutritional fluctuations (Stirrat, 2003). Urea was also significantly higher in bettongs post-reintroduction, and previous studies of wallaroos, western grey kangaroos, agile wallabies and tammar wallabies have demonstrated a relationship between poor-quality diets or reduced protein intake and low urea concentrations (Ealey \& Main, 1967; Algar et al., 1988; Stirrat, 2003; Robert \& Schwanz, 2013). However, urea was not positively related to weight in this study, and its usefulness as a potential measure of diet quality or protein intake in eastern bettongs is unclear.

An association between triglycerides and kidney fat, a traditional measure of body condition in ungulate species, has been demonstrated in Iberian wild goats Capra pyrenaica (Serrano et al., 2008). In macropodoids, triglycerides have been positively correlated with body condition index in tammar wallabies but not in agile wallabies (Stirrat, 2003; Robert \& Schwanz, 2013). The positive correlation between triglycerides and body weight in this study suggests that triglycerides may be a useful indicator of body condition in eastern bettongs.

Somewhat unexpectedly, given the observed changes in other parameters, neither total protein nor albumin differed significantly in eastern bettongs post-reintroduction. However, globulins were significantly higher post-reintroduction but were not positively correlated with weight. Total protein and albumin have been used as indicators of body condition in ungulates (Bahnak et al., 1979; Caldeira et al., 2007). Albu$\mathrm{min}$ is positively correlated with body condition index in tammar wallabies (Robert \& Schwanz, 2013) and total protein and albumin are associated with protein intake in agile wallabies (Stirrat, 2003). The relationship between total proteins, globulins and albumin and body weight in eastern bettongs requires further investigation.

Creatine kinase and aspartate amino transferase values were approximately 20- and four-fold lower, respectively, post-reintroduction. These differences can be explained by the prolonged period of confinement and transport (up to 18 hours) prior to sampling at translocation compared with the relatively short period of confinement in traps for sampling post-reintroduction. The initial values probably reflect exertional myopathy, and the values obtained postreintroduction probably reflect more normal values for this species (Portas et al., 2014). Post-reintroduction creatine kinase values are comparable with those obtained for another potoroid marsupial, Gilbert's potoroo Potorous gilbertii (Vaughan et al., 2009). Significant changes in a range of other biochemical parameters, including electrolytes, are less readily explained and are of unknown clinical significance.

Parasite species are frequently lost when host species colonize a new environment (Torchin et al., 2003). The host-parasite factors that resulted in five ectoparasites failing to persist on reintroduced bettongs are unknown but could include environmental factors, changes to host physiology and immune function, host density, transmission efficiency or the lack of intermediate hosts (MacLeod et al., 2010). Twelve of the bettongs were treated with ivermectin $\left(200 \mu \mathrm{g} \mathrm{kg}^{-1}\right)$ subcutaneously at translocation to reduce (but not eliminate) gastrointestinal nematode burdens (Portas et al., 2014). However, the ectoparasites that failed to persist on these individuals also failed to persist on untreated conspecifics at translocation, making treatment with ivermectin an unlikely explanation for their disappearance. Furthermore, two of the ectoparasites that failed to persist were fleas against which ivermectin is ineffective.

Of the four novel parasites detected post-reintroduction, Paraheterodoxus erinaceus has been reported previously from long-nosed potoroos Potorous tridactylus in Tasmania; Hetrodoxus ualabati has been reported from the swamp wallaby Wallabia bicolor in Victoria, New South Wales and Queensland; Eutrombicula macropus has been reported from macropodoids in the Northern Territory, Queensland, Victoria and South Australia; and Guntheria shareli has been reported from the red-legged pademelon Thylogale stigmatica and the bush rat Rattus fuscipes in north Queensland (von Kéler, 1971; Domrow \& Lester, 1985; Portas et al., 2009). Sympatric macropodoids were the most likely source of Paraheterodoxus erinaceus and Eutrombicula macropus; the macropodoid host species for these parasites are present in the Australian Capital Territory, including a population of long-nosed potoroos at Tidbinbilla Nature Reserve. Of the two previously reported hosts for Guntheria shareli only the bush rat occurs in the Australian Capital Territory, and thus represents the most likely source of this ectoparasite. However, identification was based solely on morphological features of the scutum, which may have been damaged in preparation of skin scrapings, hence our designation G. cf. shareli. Similarly, variation in the distribution of setae on females of the Heterodoxus species recovered compared with that described in the published key for the genus (von Kéler, 1971) may or may not represent normal anatomical variation, hence our designation $H$. cf. ualabati. The swamp wallaby, sympatric at both reintroduction sites, is the most likely source of this louse species.

Serum-virus neutralization assays were used to detect antibodies against MaHV-1 and MaHV-2 (alphaherpesviruses) in serum samples, whereas PCR was used to detect any herpesvirus DNA (including the gammaherpesvirus, PotHV-1) in swab samples. The changing antibody and PCR status observed in a small number of bettongs is consistent with observations in other species, where herpesvirus shedding has been detected intermittently following periodic reactivation from latency (Roizman \& Pellett, 2001). Similarly, one individual was seropositive at translocation 
but seronegative post-reintroduction. Serum antibodies to herpesviruses generally persist over time but antibody levels can decrease in some individuals and fall below detectable levels, particularly in the absence of reinfection or reactivation (Van Der Poel et al., 1995; Kaashoek et al., 1996; Whitley, 2001). Reactivation of latent herpesvirus infections often occurs during periods of host immune-compromise or stress; a study in Australian marsupials identified poor body condition score as a risk factor for herpesvirus shedding (Stalder et al., 2015). The higher body weights and changes to haematological and biochemical parameters suggestive of improved nutritional status could therefore help to explain why these viruses were not detected post-reintroduction. However, further studies are required to investigate this hypothesis, particularly as the rate of herpesvirus infection detected at translocation was low.

In conclusion, we found that the body weight of eastern bettongs increased significantly post-reintroduction but was not significantly different between reintroduction sites or between the sexes in response to reintroduction. A range of haematological and biochemical parameters changed post-reintroduction but there were few differences between reintroduction sites or between the sexes in response to reintroduction. Specifically, haemoglobin, red cell count, haematocrit, creatinine and triglycerides increased and were positively related to weight, providing potentially useful proxies for assessing the nutritional status of eastern bettongs, and hence the suitability of their habitat. Given that all individuals studied survived post-reintroduction, we were unable to establish if any of the variables might be useful predictors of survival. Of the infectious diseases and parasites considered, none impacted overall translocation success or individual survival. However, ongoing monitoring is recommended, as these diseases and parasites could be expected to be of greater importance in suboptimal habitats. The health of eastern bettongs appeared to improve following reintroduction from Tasmania to the Australian Capital Territory. This study demonstrates the value of comprehensive and ongoing health evaluation during reintroduction programmes. By assessing these health parameters we were able to record the physiological response of eastern bettongs to reintroduction, and gain additional information not attained with standard measures of reintroduction success, such as survival and fecundity. We recommend that comprehensive and ongoing health evaluations be incorporated into future reintroductions of the eastern bettong and into wildlife reintroductions more broadly, to facilitate more accurate assessment of reintroduction outcomes.

\section{Acknowledgements}

All procedures were approved by the Australian National University Animal Experimentation Ethics Committee (ethics protocol A2011/o17). Funding was provided by the Australian Capital Territory Government and an Australian Research Council Linkage Grant (LP110100126). ADM was supported by an Australian Research Council Future Fellowship (FT100100358). We thank the Tasmanian Department of Primary Industries, Parks, Water and Environment for assistance with the original reintroduction. We acknowledge Don Fletcher, Andrea Reiss, Peter Holz, Kate Grarock, Elyce Fraser, Ani Kunz, David Dobroszczyk, Scott Ryan, Kym Birgan, Helen Crisp, Claire Wimpenny, Mel Snape, Nicola Munro and Jenny Newport for logistical support. We thank Saul Cunningham, Iain Gordon, Daniel Iglesias, Margaret Kitchin and Sue McIntyre for advice and support. We acknowledge Mulligans Flat-Goorooyaroo Woodland Experiment and Mulligans Flat Woodland Sanctuary for supporting the translocation.

\section{References}

Algar, D., Arnold, G.W. \& Grassia, A. (1988) Effects of nitrogen and season on western grey kangaroo hematology. The Journal of Wildlife Management, 52, 616-619.

Bahnak, B.R., Holland, J.C., Verme, L.J. \& Ozoga, J.J. (1979) Seasonal and nutritional effects on serum nitrogen constituents in white-tailed deer. The Journal of Wildlife Management, 43, 454-46o.

Batson, W., Fletcher, D., Portas, T., Crisp, H., Ryan, S., Wimpenny, C. et al. (in press) Reintroduction of eastern bettong to a critically endangered woodland habitat in the Australian Capital Territory, Australia. IUCN Global Re-introduction Perspectives Series.

Batson, W.G., Gordon, I.J., Fletcher, D.B. \& Manning, A. (2015) The effect of pre-release captivity on post-release performance in reintroduced eastern bettongs Bettongia gaimardi. Oryx, http://dx. doi.org/10.1017/So030605315000496.

Cabezas, S., Calvete, C. \& Moreno, S. (2011) Survival of translocated wild rabbits: importance of habitat, physiological and immune condition. Animal Conservation, 14, 665-675.

Caldeira, R.M., Belo, A.T., Santos, C.C., Vazques, M.I. \& Portugal, A.V. (2007) The effect of long-term feed restriction and over-nutrition on body condition score, blood metabolites and hormonal profiles in ewes. Small Ruminant Research, 68, 242-255.

Claridge, A.W., Seebeck, J. \& Rose, R.W. (2007) Bettongs, Potoroos and the Musky Rat-kangaroo. CSIRO Publishing, Collingwood, Australia.

Clarke, J., Warren, K., Calver, M., De Tores, P., Mills, J. \& Robertson, I. (2013) Hematologic and serum biochemical reference ranges and an assessment of exposure to infectious diseases prior to translocation of the threatened western ringtail possum (Pseudocheirus occidentalis). Journal of Wildlife Diseases, 49, 831-840.

Deem, S.L., Cruz, M.B., Higashiguchi, J.M. \& Parker, P.G. (2012) Diseases of poultry and endemic birds in Galapagos: implications for the reintroduction of native species. Animal Conservation, 15, $73-82$.

Delgiudice, G.D., Mech, L.D. \& Seal, U.S. (1990) Effects of winter undernutrition on body composition and physiological profiles of white-tailed deer. The Journal of Wildlife Management, 54, 539-550.

Domrow, R. \& Lester, L.N. (1985) Chiggers of Australia (Acari: Trombiculidae): an annotated checklist, keys and bibliography. Australian Journal of Zoology Supplement Series, 33, 1-111. 
Ealey, E.H.M. \& Main, A.R. (1967) Ecology of the euro, Macropus robustus (Gould), in north-western Australia. III. Seasonal changes in nutrition. Wildlife Research, 12, 53-65.

Ewen, J.G., Acevedo-Whitehouse, K., Alley, M.R., Carraro, C., Sainsbury, A.W., Swinnerton, K. \& Woodroffe, R. (2012) Empirical consideration of parasites and health in reintroduction. In Reintroduction Biology: Integrating Science and Management (eds J.G. Ewen, D.P. Armstrong, K.A. Parker \& P.J. Seddon), pp. 290-335. Wiley-Blackwell, Oxford, UK.

GreEN, A.J. (2001) Mass/length residuals: measures of body condition or generators of spurious results? Ecology, 82, 1473-1483.

Jakob-Hoff, R.M., MacDiarmid, S.C., Lees, C., Miller, P.S., Travis, D. \& Koск, R. (2014) Manual of Procedures for Wildife Disease Risk Analysis. World Organisation for Animal Health, Paris, France. Published in association with the International Union for Conservation of Nature and the Species Survival Commission.

Johnson, A.M., Roberts, H., Statham, P. \& Munday, B.L. (1989) Serodiagnosis of acute toxoplasmosis in macropods. Veterinary Parasitology, 34, 25-33.

Johnson, C.N. (1994) Nutritional ecology of a mycophagous marsupial in relation to production of hypogeous fungi. Ecology, 75, 2015-2021.

Johnson, C.N. \& McIlwee, A.P. (1997) Ecology of the northern bettong, Bettongia tropica, a tropical mycophagist. Wildlife Research, 24, 549-559.

Kaashoek M.J., Rijsewijk F.A.M. \& Van Oirschot J.T. (1996) Persistence of antibodies against bovine herpesvirus 1 and virus reactivation two to three years after infection. Veterinary Microbiology, 53, 103-110.

Kock R.A., Soorae P.S. \& Mohammed, O.B. (2007) Role of veterinarians in re-introductions. International Zoo Yearbook, 41, 24-37.

LEIGHTON, F.A. (2002) Health risk assessment of the translocation of wild animals. Scientific and Technical Review of the International Office of Epizootics, 21, 187-195.

Maceda-Veiga, A., Figuerola, J., Martinez-Silvestre, A., Viscor, G., Ferrari, N. \& Pacheco, M. (2015) Inside the redbox: applications of haematology in wildlife monitoring and ecosystem health assessment. Science of the Total Environment, 514 322-332.

MacLeod, C.J., Paterson, A.M., Tompkins, D.M. \& Duncan, R.P. (2010) Parasites lost-do invaders miss the boat or drown on arrival? Ecology Letters, 13, 516-527.

Manning, A.D., Wood, J.T., Cunningham, R.B., McIntyre, S., Shorthouse, D.J., Gordon, I.J. \& Lindenmayer, D.B. (2011) Integrating research and restoration: the establishment of a long-term woodland experiment in south-eastern Australia. Australian Zoologist, 35, 633-648.

Mathews, F., Moro, D., Strachan, R., Gelling, M. \& Buller, N. (2006) Health surveillance in wildlife reintroductions. Biological Conservation, 131, 338-347.

Nichols, J.D. \& Armstrong, D.P. (2012) Monitoring for reintroductions. In Reintroduction Biology: Integrating Science and Management (eds J.G. Ewen, D.P. Armstrong, K.A. Parker \& P.J. Seddon), pp. 223-255. Wiley-Blackwell, Oxford, UK.

Pacioni, C., Robertson, I.D., Maxwell, M., van Weenen, J. \& WAYNE, A.F. (2013) Hematologic characteristics of the woylie (Bettongia penicillata ogilbyi). Journal of Wildlife Diseases, 49, 816-830.

Portas, T.J., Crowley, A. \& Hufschmid, J. (2009) Ectoparasitic dermatitis in free-ranging swamp wallabies (Wallabia bicolor) in New South Wales. Australian Veterinary Journal, 87, $160-162$
Portas, T.J., Fletcher, D., Spratt, D., Reiss, A., Holz, P., STALDER, K. et al. (2014) Health evaluation of free-ranging eastern bettongs (Bettongia gaimardi) during translocation for reintroduction in Australia. Journal of Wildlife Diseases, 50, 210-223.

Robert, K.A. \& Schwanz, L.E. (2013) Monitoring the health status of free-ranging tammar wallabies using hematology, serum, biochemistry, and parasite loads. The Journal of Wildlife Management, 77, 1232-1243.

Roizman, B. \& Pellett, P.E. (2001) The family Herpesviridae: a brief introduction. In Fields Virology, 4th edition (eds D.M. Knipe \& P.M. Howley), pp. 2381-2397. Lippincott Williams \& Wilkins, Philadelphia, USA.

Schultz, D.J., Rich, B.G., Rohrig, W., McCarthy, P.J., Mathews, B., SChultz, T.J. et al. (2011) Investigations into the health of brush-tailed rock-wallabies (Petrogale penicillata) before and after reintroduction. Australian Mammalogy, 33, 235-244.

Serrano, E., González, F.J., Grandos, J.E., Moço, G., Fandos, P., Soriguer, R.C. \& Pérez, J.M. (2008) The use of total serum proteins and triglycerides for monitoring body condition in the Iberian wild goat (Capra pyrenaica). Journal of Zoo and Wildlife Medicine, 39, 646-649.

Shield, J. (1971) A seasonal change in the blood cell volume of the Rottnest Island quokka, Setonix brachyurus. Journal of Zoology, 165, 343-354.

Shorthouse, D.J., Iglesias, D., Jeffress, S., Lane, S., Mills, P., Woodbridge, G. et al. (2012) The 'making of Mulligans FlatGoorooyaroo experimental restoration project. Ecological Management \& Restoration, 13, 112-125.

Spencer, P.B.S. \& Speare, R. (1992) Hematology of wild allied rock-wallabies, Petrogale assimilis Ramsay, 1877 (Marsupialia: Macropodidae), in North Queensland. Australian Journal of Zoology, 40, 355-364.

Stalder, K., Vaz, P.K., Gilkerson, J.R., Baker, R., Whiteley, P., Ficorilli, N. et al. (2015) Prevalence and clinical significance of herpesvirus infection in populations of Australian marsupials. PLoS ONE, 10(7), e0133807.

Stirrat, S. (2003) Body condition and blood chemistry of agile wallabies (Macropus agilis) in the wet-dry tropics. Wildlife Research, 30, 59-67.

Sтоскнам, S.L. \& Sсотт, M.A. (2008) Fundamentals of Veterinary Clinical Pathology, 2nd edition. Blackwell Publishing, Ames, USA.

Torchin, M.E., Lafferty, K.D., Dobson, A.P., McKenzie, V.J. \& KURIS, A.M. (2003) Introduced species and their missing parasites. Nature, 421, 628-630.

Travis, D.A., Hungerford, L., Engel, G.A. \& Jones-Engel, L. (2006) Disease risk analysis: a tool for primate conservation planning and decision making. American Journal of Primatology, 68, 855-867.

Van Der Poel, W.H., Kramps, J.A., Quak, J., Brand, A. \& Van Oirschot, J.T. (1995) Persistence of bovine herpesvirus-1-specific antibodies in cattle, after intranasal vaccination with a live virus vaccine. Veterinary Record, 137, 347-348.

Vaughan, R.J., Warren, K.S., Mills, J.S., Palmer, C., Fenwick, S., Monaghan, C.L. \& Friend, A.J. (2009) Hematological and serum biochemical reference values and cohort analysis in the Gilbert's potoroo (Potorous gilbertii). Journal of Zoo and Wildlife Medicine, 40, 276-288.

Vaz, P.K., Motha, J., McCowan, C., Ficorilli, N., Whitely, P.L., WILKS, C.R. et al. (2013) Isolation and characterization of a novel herpesvirus from a free-ranging eastern grey kangaroo (Macropus giganteus). Journal of Wildlife Diseases, 49, 143-151. 
von Kéler, S. (1971) A revision of the Australasian Boopiidae (Insecta: Phthiraptera), with notes on the

Trimenoponidae. Australian Journal of Zoology Supplementary Series, 6, 1-126.

Webster, K.N., Hill, N.J., Burnett, L. \& Deane, E.M. (2014) Ectoparasite infestation patterns, haematology and serum biochemistry of urban-dwelling common brushtail possums. Wildlife Biology, 20, 206-216.

Whitley, R.J. (2001) Herpes simplex viruses. In Fields Virology, 4th edition (eds D.M. Knipe \& P.M. Howley), pp. 2461-2509. Lippincott Williams \& Wilkins, Philadelphia, USA.

Work, T.M., Klavitter, J.L., Reynolds, M.H. \& Blehert, D. (2010) Avian botulism: a case study in translocated endangered Laysan ducks (Anas laysanensis) on Midway Atoll. Journal of Wildlife Diseases, 46, 499-506.

\section{Biographical sketches}

Tiмотну Portas is a wildlife veterinarian whose work encompasses reintroduction programmes and diseases of free-ranging wildlife. Ross CUNNINGHAM is a statistician who works in the field of conservation and landscape ecology. DAVID SPRATT is a parasitologist who studies host-parasite relationships in Australian fauna. JO A NNE DE V LIN's research focuses on the pathogenesis and epidemiology of viral diseases in wildlife and domestic animals. Peter Holz is a wildlife veterinarian whose research includes Australian marsupials and bats. WILLIA M BATSON specializes in reintroduction biology, including the tactical manipulation of applied processes. JANE OWENs's work includes the epidemiology of infectious disease in wild and domestic animals. Adrian Manning conducts research in the field of landscape ecology, conservation biology and restoration ecology. 